\title{
UV-VIS, NMR AND FT-IR SPECTRA OF TAUTOMERS OF VITAMIN C. EXPERIMENTAL AND DFT CALCULATIONS
}

\author{
HOSSEIN A. DABBAGH, FATEMEH. AZAMI, HOSSEIN FARROKHPOUR, \\ ALIREZA NAJAFI CHERMAHINI*
}

Department of Chemistry, Isfahan University of Technology, 8415483111 Isfahan, Iran

\begin{abstract}
Experimental and computational analysis of spectroscopic parameters of L-ascorbic acid (vitamin C) and its tautomers was investigated by Density Functional Theory (DFT) using B3LYP method. The optimized geometries and calculated vibrational frequencies were evaluated. The latter was compare with those of experimental values. The $\lambda_{\max }$ values of L-ascorbic acid were found $259(\mathrm{at} \mathrm{pH}=3)$ experimentally, 238 and $247 \mathrm{~nm}$ calculated in the gas and water phase at TD-DFT methods, respectively. The experimental order of $v(\mathrm{O}-\mathrm{H})$ modes was obtained at $\mathrm{v}\left(\mathrm{O}_{3}-\mathrm{H}_{3}\right)>\left(\mathrm{O}_{6}-\mathrm{Ho}_{6}\right)>\left(\mathrm{O}_{2}-\mathrm{H}_{2}\right)>\left(\mathrm{O}_{5}-\mathrm{Ho}_{5}\right)$. The theoretical orders were calculated at $\left.v) \mathrm{O}_{6}-\mathrm{Ho}_{6}\right)>\left(\mathrm{O}_{2}-\mathrm{H}_{2}\right)>\left(\mathrm{O}_{5}-\mathrm{Ho}_{5}\right)>\left(\mathrm{O}_{3}-\mathrm{H}_{3}\left(\right.\right.$ and $v\left(\mathrm{O}_{3}-\mathrm{H}_{3}\right)>\left(\mathrm{O}_{5}-\mathrm{Ho}_{5}\right)>\left(\mathrm{O}_{6}-\mathrm{Ho}_{6}\right)>\left(\mathrm{O}_{2}-\mathrm{H}_{2}\right)$, respectively, in the gas phase and aqueous phase. The highest wave number of tautomers $(S, Z)$-3,5,6-trihydroxy-2-oxohex-3-enoic acid (2), (2Z,4E)-2,3,5,6-tetrahydroxyhexa-2,4-dienoic acid (3), $(R)$-2-( $(S)$-1,2dihydroxyethyl)-4,5-dihydroxyfuran-3(2H)-one (4) was calculated for the stretching modes $\mathrm{O}_{6}-\mathrm{Ho}_{6}, \mathrm{O}_{3}-\mathrm{H}_{3}, \mathrm{O}_{6}-\mathrm{Ho}_{6}$ bonds, respectively, in the gas phase. The experimental and theoretical calculations of proton NMR predicted $\mathrm{H}_{3}$ as the most deshilded proton.
\end{abstract}

Keywords: Vitamin C, tautomers, UV-VIS, NMR, FT-IR

\section{INTRODUCTION}

Ascorbic acid (AA) is one of the interesting and well known acids in nature which is synthesized from D-glucose or D-galactose [1]. Generally, AA is used in pharmaceutical, chemical, cosmetic and food industry due to its bioactivity and as antioxidant [2]. The lack of ascorbic acid leads to scurvy [3]. Ascorbic acid is known to increase the accessibility and absorption of iron from non-heme iron sources [4]. Vitamin $\mathrm{C}$ has been demonstrated to kill HIV-positive cells and help HIV-positive individuals by increasing the immune system [5]. Vitamin C significantly decreases the adverse effect of reactive species such as reactive oxygen and nitrogen that can cause oxidative damage to macromolecules such as lipids, DNA and proteins[6]. Ascorbic acid radical produced by the anodic oxidation of ascorbic acid was detected using UV spectroscopy [7]. Y. Dimitrova, studied the hydrogen-bonded system formed between L-ascorbic acid and five water molecules [8]. R. A. Yadav et al. studied the neutral L-ascorbic acid molecule and its cation and anion [9]. J.N. Patricia observed benzene formation in certain beverages containing benzoic and ascorbic acids under heat and UV exposure [10]. D. Giuntini et al. investigated ascorbic acid content in tomato fruits under UV-B radiation [11]. A method for the simultaneous measurement of ascorbic acid and uric acid in human seminal plasma has been described using HPLC with UV detector [12]. A.R. Wedina et al. applied solid-phase UV spectrophotometer technique to measure ascorbic acid[13]. M. Surmeian described new method for resolving three-component drug mixture[14]. H.F. Ji and E. L. Shen studied quenching mechanisms of triplet state riboflavin by vitamin C [15-17]. J.R. Juhasz et al. studied the effects of conformation on the acidity of L-ascorbic acid [18]. The role of the ascorbic acid concentration in the formation of gold nanorods was studied by UV-vis absorption and transmission electron microscopy[19]. I. Georgieva et al. reported DFT study of four low-energy neutral, four anion and two dianion conformers of AA [20]. Natural abundance ${ }^{17} \mathrm{O}-\mathrm{NMR}$ spectra of $\mathrm{L}$-ascorbic acid were recorded in aqueous solution as a function of $\mathrm{pH}$ by A. Ruchmann et al. [21]. M. B. Damian et al. studied two stable conformers of L-ascorbic acid and its fully oxidized form [22]. Ab inito conformational studies were performed on all local and global minima of PES at the MP2/6$311 \mathrm{G}(\mathrm{d}, \mathrm{p})$ level of theory [23]. Gino A. and co-workers reported the correlation between ascorbate anion (AH2) and its oxidation products [24].

The stability of Vitamin C is under scrutiny. It may be decompose at room temperature when is expose to air or during cooking process. It is very sensitive to heat, alkali, oxygen, light and even moisture [1]. Traces of copper (II) and iron (III) can deeply accelerate the oxidation in aqueous solution [2]. The degradation of vitamin $\mathrm{C}$ may coincide with isomerization, tautomerism or racemization.

In this report, experimental and computational analysis of spectroscopic parameters (FT-IR, UV, ${ }^{1} \mathrm{H}-\mathrm{NMR}$ and ${ }^{13} \mathrm{C}-\mathrm{NMR}$ ) of L-ascorbic acid and three (potential side products) of its tautomers [(S,Z)-3,5,6-trihydroxy-2-oxohex3 -enoic acid (2), (2Z,4E)-2,3,5,6-tetrahydroxyhexa-2,4-dienoic acid (3), $(R)$ 2-((S)-1,2-dihydroxyethyl)-4,5-dihydroxyfuran-3(2H)-one (4)] (Fig. 1) was investigated by Density Functional Theory (DFT) using B3LYP method. The tautomerization of vitamin $\mathrm{C}$ to symmertical tautomers may result in $\mathrm{VC}$ racemization during storage or cooking. The UV, NMR and IR of the mixture may help measure the tautomers contents. The optimized geometries and calculated vibrational frequencies are evaluated and compared with those of experimental values.

\section{COMPUTATIONAL METHOD}

L-Ascorbic acid and its tautomers were fully optimized at the B3LYP/6$31++\mathrm{G}(\mathrm{d}, \mathrm{p})$ level of theory. The FT-IR and UV-Vis spectra were computed at the same level of theory using the GAUSSIAN 03 program [25]. The theoretical electronic absorption spectra were calculated using TD-DFT methods. Calculations of ${ }^{1} \mathrm{H}-\mathrm{NMR}$ and ${ }^{13} \mathrm{C}$-NMR were performed at the GIAO/B3LYP/6-31+G(2d, p) levels of theory (at TMS/GIAO/B3LYP/6$311+\mathrm{G}(2 \mathrm{~d}, \mathrm{p}))$. The calculations were performed for two solvent (DMSO and water using the polarizable continuum model (PCM) [26-29].

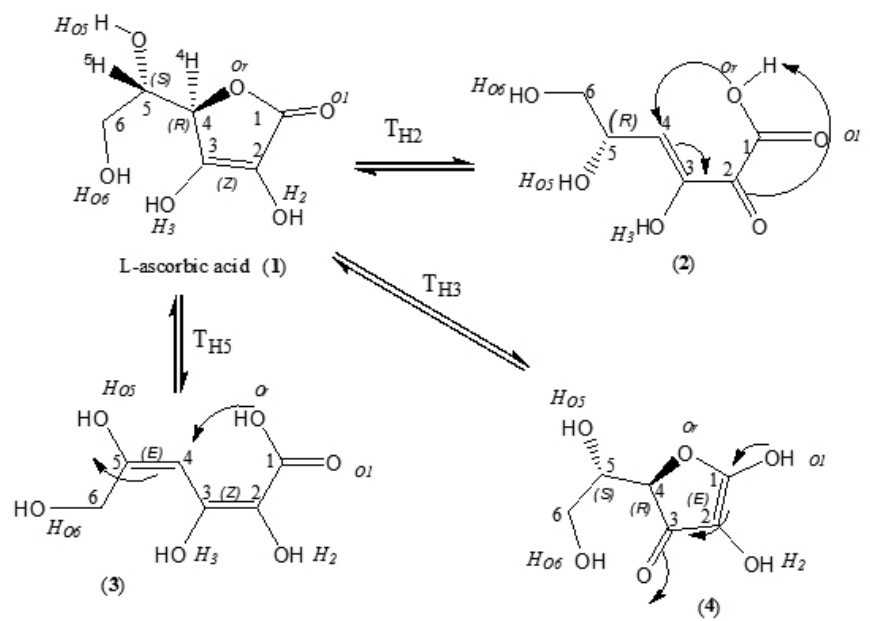
$\mathrm{H}_{3}$ (4).

Fig. 1. L-ascorbic acid (1) and its proton tautomers $\mathrm{H}_{2}(2), \mathrm{H}_{5}(3)$ and 


\section{EXPERIMENTS}

L-Ascorbic acid [(4R-5S)-AA] compound (1) was purchased from Acros Organics Chemical Co. It was used as such without further purification. The IR spectra were recorded in $\mathrm{KBr}$ pellets using a JASCO FT-IR-680 Plus spectrometer in the spectral range 400-4000 $\mathrm{cm}^{-1}$. ${ }^{1} \mathrm{H}-\mathrm{NMR}$ and ${ }^{13} \mathrm{C}-\mathrm{NMR}$ spectra in $\mathrm{D}_{2} \mathrm{O}$ and DMSO were recorded by a Bruker Avance 400 spectrometer. UV-Vis spectra in deionized water were recorded by a UVD2950 LABOMED, INC spectrophotometer.

\section{RESULTS AND DISCUSSION}

Ascorbic acid (1) is known to be unstable molecule which easily undergoes isomerization, decomposition and/or racemization. In this report, spectroscopic analysis (UV-Vis, NMR and FT-IR) of vitamin C tautomers 2-4 was investigated. The structure, numbering and proton tautomers $\mathrm{H}_{2}(2)$, $\mathrm{H}_{5}(\mathbf{3})$ and $\mathrm{H}_{3}(4)$ of L-ascorbic acid are presented in Figure 1. The relative energy of $1,2,3$ and $\mathbf{4}$ was calculated $0,3.8,5.5$ and $5.6 \mathrm{kcal} / \mathrm{mol}$ at B3LYP/6$31++\mathrm{G}(\mathrm{d}, \mathrm{p})$ level of theory, respectively. The tautomerization of $\mathrm{H} 4$ produces very unstable isomer (dihydroxyfuran-3-one derivative) with relative energy of $24.1 \mathrm{kcal} / \mathrm{mol}$ was excluded from this study.

\section{1 The UV-visible spectrum}

The observed and calculated visible absorption maxima of the compounds 1-4 are given in Table 1. The single-excitation configuration interaction timedependent density functional theory (TD-DFT) calculations of molecular orbital geometry in the gas and water phase show that visible absorption maxima of L-ascorbic acid correspond to electron transition from HOMO to LUMO. The maximum amount of $\mathrm{f}$ values with highest $\%$ was obtained for these electronic transitions at $\lambda$ max. The $\lambda$ max value for $\mathrm{L}$-ascorbic acid was found at 238 $\mathrm{nm}$ in the gas phase. This value was increased to $248 \mathrm{~nm}$ in the water (solvent effects). The calculated $\lambda_{\max }$ values in the gas phase for the compounds $\mathbf{2}, \mathbf{3}, \mathbf{4}$ were found at 342,309 and $273 \mathrm{~nm}$, respectively. The greater $\lambda_{\max }$ value for $\mathbf{2}$ is attributed to extra conjugation. Based on the f values collected in Table 1, it is evident that absorption maxima of $\mathbf{2 , 3}$ and $\mathbf{4}$ correspond to the electron transition from HOMO to LUMO.

Table 1. The energy and molar absorption coefficients of experimental absorption bands and the electronic transitions calculated with TD-DFT method for L-ascorbic acid and its tautomers.

\begin{tabular}{|l|c|c|c|}
\hline \multicolumn{3}{|c|}{ Compound (1) in gas phase } \\
\hline $\begin{array}{l}\text { The most important orbital } \\
\text { excitations }\end{array}$ & $(\mathrm{nm}) \lambda$ & $\mathrm{E}(\mathrm{eV})^{\mathrm{a}}$ & $\mathrm{f}^{\mathrm{b}}$ \\
\hline $\mathrm{H} \rightarrow \mathrm{L}^{\mathrm{c}}(27 \%)^{\mathrm{d}}$ & 247.4 & 5.012 & 0.0181 \\
\hline $\mathrm{H} \rightarrow \mathrm{L}+1(+45 \%)$ & 247.4 & 5.012 & 0.0181 \\
\hline $\mathrm{H} \rightarrow \mathrm{L}+2(25 \%)$ & 247.4 & 5.012 & 0.0181 \\
\hline $\mathrm{H}-1 \rightarrow \mathrm{L}(18 \%)\left[^{*}\right]$ & 238.02 & 5.2089 & 0.1075 \\
\hline $\mathrm{H}-1 \rightarrow \mathrm{L}+1$ & 238.02 & 5.2089 & 0.1075 \\
\hline $\mathrm{H} \rightarrow \mathrm{L}(+41 \%)[*]$ & 238.02 & 5.2089 & 0.1075 \\
\hline $\mathrm{H} \rightarrow \mathrm{L}+1$ & 238.02 & 5.2089 & 0.1075 \\
\hline $\mathrm{H} \rightarrow \mathrm{L}+2$ & 238.02 & 5.2089 & 0.1075 \\
\hline $\mathrm{H}-1 \rightarrow \mathrm{L}(+65 \%)[*]$ & 234.08 & 5.2967 & 0.0267 \\
\hline $\mathrm{H}-1 \rightarrow \mathrm{L}+1$ & 234.08 & 5.2967 & 0.0267 \\
\hline $\mathrm{H} \rightarrow \mathrm{L}$ & 234.08 & 5.2967 & 0.0267 \\
\hline $\mathrm{H} \rightarrow \mathrm{L}+2$ & 234.08 & 5.2967 & 0.0267 \\
\hline
\end{tabular}

Compound (2) in gas phase

\begin{tabular}{|l|c|c|c|}
\hline $\begin{array}{l}\text { The most important orbital } \\
\text { excitations }\end{array}$ & $(\mathrm{nm}) \lambda$ & $\mathrm{E}(\mathrm{eV})$ & $\mathrm{f}$ \\
\hline $\mathrm{H}-1 \rightarrow \mathrm{L}(92 \%)\left[^{*}\right]$ & 399,67 & 3.1023 & 0.0001 \\
\hline $\mathrm{H} \rightarrow \mathrm{L}(80 \%)\left[^{*}\right]$ & 342.06 & 3.6246 & 0.1667 \\
\hline $\mathrm{H}-5 \rightarrow \mathrm{L}(70 \%)\left[^{*}\right]$ & 248.57 & 4.9879 & 0.0007 \\
\hline $\mathrm{H}-3 \rightarrow \mathrm{L}$ & 248.57 & 4.9879 & 0.0007 \\
\hline $\mathrm{H}-2 \rightarrow \mathrm{L}$ & 248.57 & 4.9879 & 0.0007 \\
\hline
\end{tabular}

\begin{tabular}{|c|c|c|c|}
\hline $\mathrm{H}-1 \rightarrow \mathrm{L}+2$ & 248.57 & 4.9879 & 0.0007 \\
\hline \multicolumn{4}{|c|}{ Compound (3) in gas phase } \\
\hline $\begin{array}{l}\text { The most important orbital } \\
\text { excitations }\end{array}$ & $(\mathrm{nm}) \lambda$ & $\mathrm{E}(\mathrm{eV})$ & $\mathrm{f}$ \\
\hline $\mathrm{H} \rightarrow \mathrm{L}(80 \%)[*]$ & 309.53 & 4.0055 & 0.1379 \\
\hline $\mathrm{H} \rightarrow \mathrm{L}+1$ & 309.53 & 4.0055 & 0.1379 \\
\hline $\mathrm{H}-2 \rightarrow \mathrm{L}$ & 262.18 & 4.7290 & 0.0508 \\
\hline $\mathrm{H}-1 \rightarrow \mathrm{L}(22 \%)[*]$ & 262.18 & 4.7290 & 0.0508 \\
\hline $\mathrm{H} \rightarrow \mathrm{L}+1(65 \%)[*]$ & 262.18 & 4.7290 & 0.0508 \\
\hline $\mathrm{H}-2 \rightarrow \mathrm{L}(52 \%)[*]$ & 257.65 & 4.8121 & 0.0125 \\
\hline $\mathrm{H}-2 \rightarrow \mathrm{L}+1$ & 257.65 & 4.8121 & 0.0125 \\
\hline $\mathrm{H}-1 \rightarrow \mathrm{L}$ & 257.65 & 4.8121 & 0.0125 \\
\hline $\mathrm{H} \rightarrow \mathrm{L}+1$ & 257.65 & 4.8121 & 0.0125 \\
\hline $\mathrm{H} \rightarrow \mathrm{L}+2$ & 257.65 & 4.8121 & 0.0125 \\
\hline \multicolumn{4}{|c|}{ Compound (4) in gas phase } \\
\hline $\begin{array}{l}\text { The most important orbital } \\
\text { excitations }\end{array}$ & $(\mathrm{nm}) \lambda$ & $\mathrm{E}(\mathrm{eV})$ & $\mathrm{f}$ \\
\hline $\mathrm{H}-1 \rightarrow \mathrm{L}(78 \%)[*]$ & 275.11 & 4.5068 & 0.0108 \\
\hline $\mathrm{H}-1 \rightarrow \mathrm{L}+1$ & 275.11 & 4.5068 & 0.0108 \\
\hline $\mathrm{H} \rightarrow \mathrm{L}$ & 275.11 & 4.5068 & 0.0108 \\
\hline $\mathrm{H} \rightarrow \mathrm{L}+1$ & 275.11 & 4.5068 & 0.0108 \\
\hline $\mathrm{H}-1 \rightarrow \mathrm{L}$ & 273.24 & 4.5375 & 0.0767 \\
\hline $\mathrm{H} \rightarrow \mathrm{L}(55 \%)\left[{ }^{*}\right]$ & 273.24 & 4.5375 & 0.0767 \\
\hline $\mathrm{H} \rightarrow \mathrm{L}+1$ & 273.24 & 4.5375 & 0.0767 \\
\hline $\mathrm{H} \rightarrow \mathrm{L}+2$ & 273.24 & 4.5375 & 0.0767 \\
\hline $\mathrm{H} \rightarrow \mathrm{L}$ & 261.18 & 4.7471 & 0.0539 \\
\hline $\mathrm{H} \rightarrow \mathrm{L}+1(30 \%)[*]$ & 261.18 & 4.7471 & 0.0539 \\
\hline $\mathrm{H} \rightarrow \mathrm{L}+2(47 \%)[*]$ & 261.18 & 4.7471 & 0.0539 \\
\hline \multicolumn{4}{|c|}{ Compound (1) in water phase } \\
\hline $\begin{array}{l}\text { The most important orbital } \\
\text { excitations }\end{array}$ & $(\mathrm{nm}) \lambda$ & $\mathrm{E}(\mathrm{eV})$ & $\mathrm{f}$ \\
\hline $\mathrm{H} \rightarrow \mathrm{L} \%)+80)[*]$ & 247.71 & 5.0052 & 0.2578 \\
\hline $\mathrm{H} \rightarrow \mathrm{L}+1 \%)+84)[*]$ & 234.47 & 5.2878 & 0.0066 \\
\hline $\mathrm{H} \rightarrow \mathrm{L}+2$ & 234.47 & 5.2878 & 0.0066 \\
\hline $\mathrm{H}-3 \rightarrow \mathrm{L}$ & 222.23 & 5.5791 & 0.0014 \\
\hline $\mathrm{H}-2 \rightarrow \mathrm{L} \%)+92)[*]$ & 222.23 & 5.5791 & 0.0014 \\
\hline \multicolumn{4}{|c|}{ Experimental of Compound (1) in $\mathrm{H}_{2} \mathrm{O}$} \\
\hline & $(\mathrm{nm}) \lambda$ & $\mathrm{E}(\mathrm{eV})$ & $\epsilon$ \\
\hline & 259 & 4.79 & 0.95416 \\
\hline
\end{tabular}

${ }^{\mathrm{a}} \mathrm{E}=\mathrm{hc} / \lambda$

${ }^{\mathrm{b}} f=$ calculated intensity

${ }^{c} \mathrm{H}=$ HOMO, L=LUMO

*S.I. Gorelsky, SWizard program, http://www.sg-chem.net

The energy $(\mathrm{eV})$ and selected HOMO-LUMO contours of L-ascorbic acid (1) in water and in gas phase are depicted in Figures 2 and 3. The energy of HOMO and LUMO for 1 was calculated -6.53 and $-1.18 \mathrm{eV}$ in aqueous phase and -6.67 and $-1.17 \mathrm{eV}$ in gas phase, respectively. The energies of the HOMO decrease in the gas phase and for LUMO is nearly the same for both phases. The energy gap $(\Delta \mathrm{E})$ for 1 was calculated 5.35 and $5.50 \mathrm{eV}$ in water and gas phase, respectively. Larger value of the energy gap implies high kinetic stability and low chemical reactivity. This is in good agreement with previous report that vitamin $\mathrm{C}$ is unstable in water [30]. The energy of HOMO and LUMO was calculated -7.11 and $-3.11 \mathrm{eV}$ for $\mathbf{2},-6.46$ and $-1.95 \mathrm{eV}$ for $\mathbf{3}$, and -6.12 and 
$-1.26 \mathrm{eV}$ for $\mathbf{4}$ in the gas phase, respectively. The energy gap $(\Delta \mathrm{E})$ for $\mathbf{2 , 3}$ and 4 was calculated $4.0,4.51$ and $4.86 \mathrm{eV}$ in gas phase, respectively, which is smaller than that of vitamin C. The energy $4.79 \mathrm{eV}$ obtained experimentally in $\mathrm{H}_{2} \mathrm{O}$ complements the theoretical value $(5.0 \mathrm{eV})$ calculated in water phase. The $\lambda_{\max }=259 \mathrm{~nm}$ obtained experimentally in $\mathrm{H}_{2} \mathrm{O}$ complements $248 \mathrm{~nm}$ value calculated in water phase.

The most important electronic transition (HOMO-LUMO) was calculated $41,80,80$ and $55 \%$ at $\lambda$ of 238.02, 342.06, 309.53 and $273.24 \mathrm{~nm}$ for $\mathbf{1}, \mathbf{2}, \mathbf{3}$ and $\mathbf{4}$, respectively in the gas phase (Table 1). This value was calculated $80 \%$ at $\lambda_{\max } 247.71$ for 1

in water phase (experimental $\lambda_{\max }=259 \mathrm{~nm}$ ). Positive values of the orbital contour are represented in brown $(+0.02 \mathrm{au})$ and negative values in green $(-0$, 02) color.
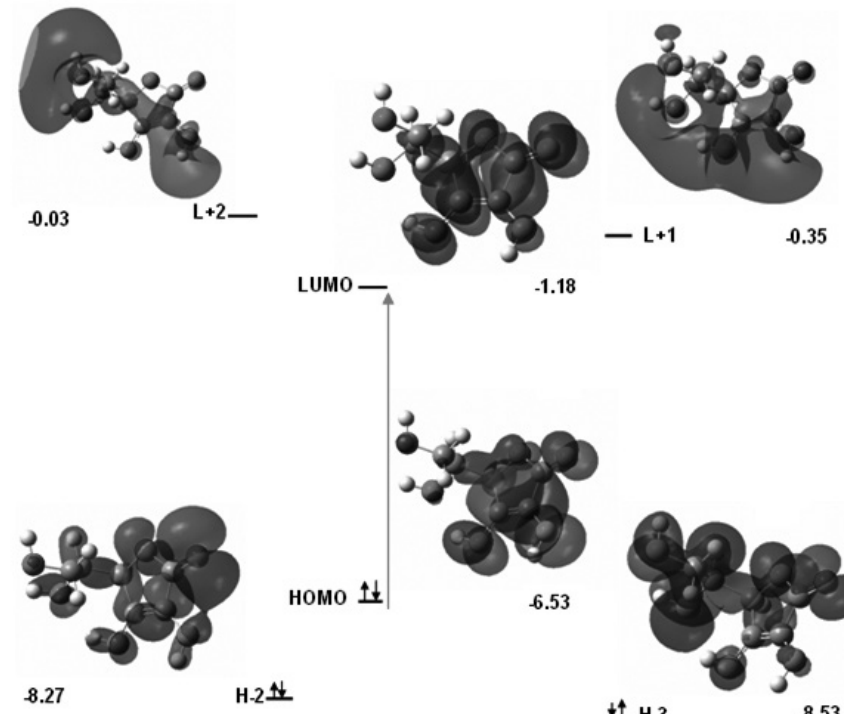

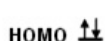
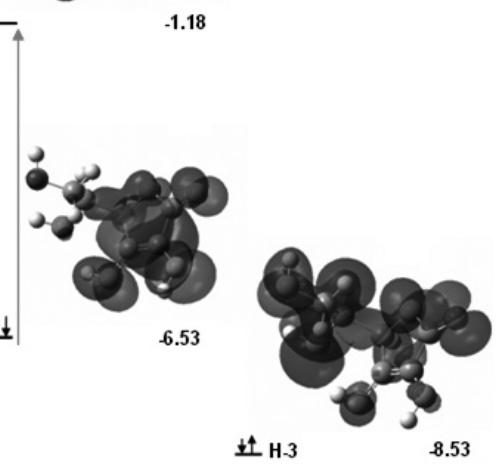

Fig. 2. Energies (eV) and selected HOMO-LUMO contours of L-ascorbic acid (1) in water.

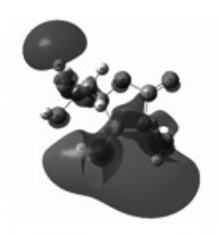

$-0.53$

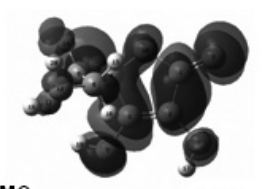

$1.17-\mathrm{L}+1$

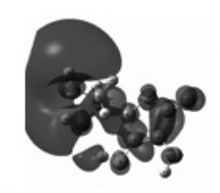

$-0.92$

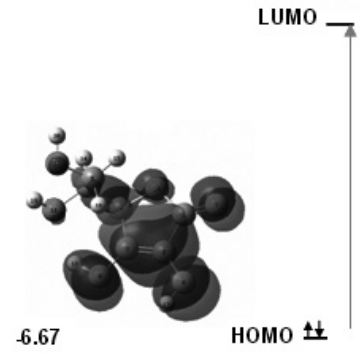

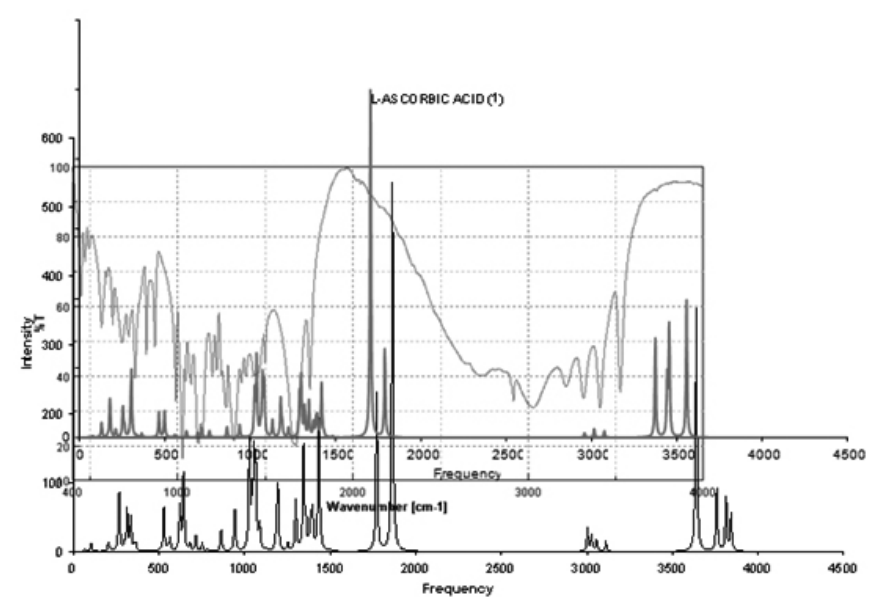

Fig. 4. Experimental $(\mathrm{KBr},-)$ and calculated infrared spectra of Lascorbic acid in the gas phase $(-)$ and in water $(-)$.

\section{2. 1 Tautomer 1 (experimental and computational)}

O-H modes. L-Ascorbic acid (1) has four $\mathrm{OH}$ groups, two being attached to the ring and two on the side chain. The order of $v(\mathrm{O}-\mathrm{H})$ modes experimentally are $\mathrm{v}\left(\mathrm{O}_{3}-\mathrm{H}_{3}\right)>\left(\mathrm{O}_{6}-\mathrm{H}_{\mathrm{O} 6}\right)>\left(\mathrm{O}_{2}-\mathrm{H}_{2}\right)>\left(\mathrm{O}_{5}-\mathrm{H}_{05}\right.$ (, in gas phase and $\left.\left.\mathrm{v}\right) \mathrm{O}_{6}-\mathrm{H}_{06}\right)$ $>\left(\mathrm{O}_{2}-\mathrm{H}_{\mathrm{O} 2}\right)>\left(\mathrm{O}_{5}-\mathrm{H}_{\mathrm{O} 5}\right)>\left(\mathrm{O}_{3}-\mathrm{H}_{3}\left(\right.\right.$ and in water phase. $\mathrm{v}\left(\mathrm{O}_{3}-\mathrm{H}_{3}\right)>\left(\mathrm{O}_{5}-\mathrm{H}_{\mathrm{O} 5}\right)>$ $\left(\mathrm{O}_{6}-\mathrm{H}_{\mathrm{O} 6}\right)>\left(\mathrm{O}_{2}-\mathrm{H}_{2}(\right.$.

Experimentally, the $\mathrm{O}_{6}-\mathrm{H}_{\mathrm{O}}$ stretching mode of the side chain of $\mathbf{1}$ was observed at $3410 \mathrm{~cm}^{-1}$. The calculated values in the gas and water phase were found $3841,3444 \mathrm{~cm}^{-1}$, respectively. The second stretching mode for the $\mathrm{O}_{2}$ $\mathrm{H}_{2}$ bond that attached to the ring were measured at 3316,3812 , and $3375 \mathrm{~cm}^{-1}$ experimentally, calculated in the gas phase and in water phase, respectively. The third stretching mode $\mathrm{O}_{5}-\mathrm{H}_{\mathrm{O}}$ in the side chain of $\mathbf{1}$ was observed experimentally at $3216 \mathrm{~cm}^{-1}$. The calculated values in the gas and water were calculated at 3758 , and $3456 \mathrm{~cm}^{-1}$, respectively. The fourth stretching mode for the $\mathrm{O}_{3}-\mathrm{H}_{3}$ bond (attached to the ring) was found at 3526,3638 , and $3558 \mathrm{~cm}^{-1}$ experimentally, in the gas phase and water, respectively.

$C=O$ mode. The stretching mode for the $\mathrm{C}_{1}=\mathrm{O}_{1}$ bond was found at 1753 , 1862 , and $1789 \mathrm{~cm}^{-1}$ experimentally, calculated in the gas phase and in aqueous phase, respectively.

$C=C$ mode. The stretching mode for the $\mathrm{C}_{2}=\mathrm{C}_{3}$ bond was found at 1672 , 1771 , and $1705 \mathrm{~cm}^{-1}$ experimentally, calculated in gas phase and in water phase, respectively.

$\mathrm{C}$ - $\mathrm{H}$ modes. The calculated stretching mode for the $\mathrm{C}_{5} \mathrm{H}_{5}$ in the side chain was found at 3003 and $2960 \mathrm{~cm}^{-1}$ in the gas phase and water phase, respectively. In addition the stretching mode for the $\mathrm{C}_{4}-\mathrm{H}_{4}$ bond in the ring was found at 2915,3027 , and $2976 \mathrm{~cm}^{-1}$ experimentally, calculated in gas and water phase, respectively. The anti-symmetric stretching mode for the $\mathrm{CH}_{2}$ group was found at 3030,3110 , and $3076 \mathrm{~cm}^{-1}$ in $\mathrm{KBr}$, calculated in the gas and water phase, respectively. The symmetric stretching mode for the $\mathrm{CH}_{2}$ was found at 2744, 3056 and $3016 \mathrm{~cm}^{-1} \mathrm{KBr}$, calculated in gas and water phase. The scissoring motion for the $\mathrm{CH}_{2}$ group in the side chain was found at 1497,1498 , and 1483 $\mathrm{cm}^{-1}$ experimentally, calculated in gas phase, and aqueous phase, respectively.

$\mathrm{C}-\mathrm{O}$ modes. The stretching mode for the $\mathrm{C}_{5}-\mathrm{O}_{5}$ bond of the side chain was found at 1120,1086 and, $1082 \mathrm{~cm}^{-1}$ experimentally, in gas and water phase, respectively. The stretching mode for the $\mathrm{C}_{6}-\mathrm{O}_{6}$ bond was found at 1076,1044 , and $1060 \mathrm{~cm}^{-1}$ in $\mathrm{KBr}$, calculated in gas and water phase. The stretching mode for the $\mathrm{C}_{1}-\mathrm{O}_{\mathrm{r}}$ bond was found at 942 , and $1130 \mathrm{~cm}^{-1}$, in gas and water phase, respectively. The stretching mode for the $\mathrm{C}_{3}-\mathrm{O}_{3}$ and $\mathrm{C}_{2}-\mathrm{O}_{2}$ groups of the ring was found at 1139 , and $1321 \mathrm{~cm}^{-1}$ in $\mathrm{KBr}$, respectively.

$C-C$ modes. The stretching mode for the $\mathrm{C}_{1}-\mathrm{C}_{2}$ was found 1126 , and $1418 \mathrm{~cm}^{-1}$ in the gas and water phase spectra, respectively. The stretching mode for the $\mathrm{C}_{4}-\mathrm{C}_{5}$ was found at $942 \mathrm{~cm}^{-1}$ in gas phase and the stretching mode for the $\mathrm{C}_{5}-\mathrm{C}_{6}$ was found at $869 \mathrm{~cm}^{-1}$ in $\mathrm{KBr}$. 
J. Chil. Chem. Soc., 59, № 3 (2014)

Table 2. Experimental $(\mathrm{KBr})$ and calculated vibrational frequencies $\left(\mathrm{cm}^{-1}\right)$ of L-ascorbic acid (1) in the gas and water at the B3LYP/6-31++G(d,p) level of theory.

\begin{tabular}{|c|c|c|c|c|c|c|c|c|c|c|c|}
\hline Exp.(ref. 9) & Gas & Water & Assignment & Exp. & Gas & Water & Assignment & Exp. & Gas & Water & Assignment \\
\hline \multirow[t]{2}{*}{3410} & \multirow[t]{2}{*}{3841} & \multirow[t]{2}{*}{3444} & \multirow[t]{2}{*}{$v_{\mathrm{O} 6-\mathrm{H}} \mathrm{O6}$} & \multirow[t]{2}{*}{1363} & \multirow[t]{2}{*}{1386} & \multirow[t]{2}{*}{1392} & \multirow[t]{2}{*}{$\begin{array}{l}\omega_{\mathrm{CH} 2} \\
\omega_{\mathrm{C} 5 \mathrm{H} 5}\end{array}$} & 988 & 862 & - & $\begin{array}{c}\rho_{\mathrm{CH} 2} \\
\delta_{\mathrm{SCSCHH6}} \\
v_{\mathrm{CS} 5-\mathrm{OS}} \\
v^{2}\end{array}$ \\
\hline & & & & & & & & 755 & & & $\delta_{\mathrm{C} 4 \mathrm{C} 5}$ \\
\hline 3316 & 3812 & 3375 & $v_{\mathrm{O} 2-\mathrm{H} 2}$ & 1221 & 1374 & 1371 & $\begin{array}{l}\rho_{\mathrm{CSH} 5} \\
\rho_{\mathrm{C} 4 \mathrm{H} 4} \\
\end{array}$ & 681 & $\begin{array}{l}780 \\
714\end{array}$ & 715 & $\alpha_{\text {ring }}$ \\
\hline 3216 & 3758 & 3456 & $v_{\mathrm{O}-\mathrm{H}} \mathrm{OS}$ & & 1357 & - & $\delta_{\text {SHбС606 }}$ & 720 & 751 & 760 & $\begin{array}{l}\gamma_{\mathrm{Cl}=\mathrm{O} 1} \\
\gamma_{\mathrm{C} 202} \\
\end{array}$ \\
\hline 3526 & 3638 & 3558 & $v_{\mathrm{O}-\mathrm{H} 3}$ & & 1343 & 1298 & $\delta_{\mathrm{SC} 3 \mathrm{O} 3 \mathrm{H} 3}$ & & & & \\
\hline 3030 & 3110 & 3076 & $\mathrm{v}_{\text {as CH2 }}$ & 1274 & 1298 & - & $\begin{array}{c}\rho_{\mathrm{CHH} 4} \\
\omega_{\mathrm{CSH} 5} \\
\delta_{\mathrm{SC} 202 \mathrm{H} 2}\end{array}$ & 628 & $\begin{array}{l}681 \\
493\end{array}$ & 691 & $\delta_{\mathrm{sc} 1 \mathrm{OrC} 4}^{v_{\mathrm{Cl}-\mathrm{C} 2}}$ \\
\hline 2744 & 3056 & 3016 & $v_{\mathrm{sCH} 2}$ & - & 1251 & - & $\begin{array}{c}\rho_{\mathrm{C} 4 \mathrm{H} 4} \\
\omega_{\mathrm{CSH} 5} \\
\delta_{\mathrm{SC} 3 \mathrm{O} 3 \mathrm{H} 3}\end{array}$ & $\begin{array}{l}565 \\
592\end{array}$ & $\begin{array}{l}643 \\
470 \\
621 \\
\end{array}$ & $\begin{array}{l}626 \\
464\end{array}$ & $\begin{array}{l}\omega_{\mathrm{C} 2 \mathrm{C} 3} \\
\omega_{\mathrm{OH} 3} \\
\omega_{\mathrm{C} 3 \mathrm{C} 4}\end{array}$ \\
\hline \multirow{3}{*}{2915} & \multirow{3}{*}{3027} & \multirow{3}{*}{2976} & \multirow{3}{*}{$\mathrm{v}_{\mathrm{C} 4-\mathrm{H} 4}$} & 1139 & & & $v_{\mathrm{C} 3-03}$ & & & & \\
\hline & & & & 1197 & & & $\tau_{\mathrm{CH} 2}$ & & & & \\
\hline & & & & $\begin{array}{l}1044 \\
1025 \\
820\end{array}$ & & & $v_{\text {ring }}$ & & & & \\
\hline- & 3003 & 2960 & $\mathrm{v}_{\mathrm{CS}-\mathrm{H} 5}$ & - & 1185 & $\begin{array}{l}3076 \\
3016\end{array}$ & $\delta_{\mathrm{SC6OGH} \mathrm{O6}}$ & & $\begin{array}{l}563 \\
551\end{array}$ & 556. & $\begin{array}{l}\omega_{\mathrm{C} 202} \\
\omega_{\mathrm{C} 303} \\
\end{array}$ \\
\hline 1753 & 1862 & 1789 & $v_{\mathrm{Cl}=\mathrm{Ol}}$ & & 1126 & 1418 & $v_{\mathrm{Cl}-\mathrm{C} 2}$ & 447 & 528 & $\begin{array}{l}262 \\
253 \\
211\end{array}$ & $\tau_{\mathrm{OSH} \mathrm{O5}}$ \\
\hline \multirow[t]{2}{*}{1672} & \multirow[t]{2}{*}{1771} & \multirow[t]{2}{*}{1705} & \multirow{2}{*}{$\mathrm{v}_{\mathrm{C} 2=\mathrm{C} 3}$} & 1120 & $\begin{array}{l}1086 \\
1055\end{array}$ & 1082 & $\begin{array}{l}v_{\mathrm{C5}-\mathrm{O} 5} \\
v_{\mathrm{CS}-\mathrm{C} 6}\end{array}$ & \multirow[t]{2}{*}{-} & \multirow[t]{2}{*}{503} & \multirow[t]{2}{*}{-} & \multirow{2}{*}{$\tau_{\mathrm{CH} 2}$} \\
\hline & & & & 869 & & & $v_{\mathrm{CS}-\mathrm{C} 6}$ & & & & \\
\hline 1497 & 1498 & 1483.31 & $\delta_{\mathrm{SCH} 2}$ & - & 1064 & 1130 & $\begin{array}{c}v_{\mathrm{Cl}-\mathrm{Or}} \\
\tau_{\mathrm{CH} 2}\end{array}$ & & $\begin{array}{l}334 \\
364 \\
356 \\
313 \\
297\end{array}$ & $\begin{array}{c}351 \\
128 \\
56 \\
-42\end{array}$ & $\omega_{\mathrm{O} 2 \mathrm{H} 2}$ \\
\hline- & 1446 & 1431 & $\begin{array}{c}\omega_{\mathrm{CSH} 5} \\
\omega_{\mathrm{O} 5 \mathrm{H} \mathrm{O5}} \\
\end{array}$ & & & & & & 266 & 163 & $\omega_{\mathrm{O} 6 \mathrm{H}}$ O6 \\
\hline 1248 & 1432 & 1418 & $\begin{array}{l}\delta_{\mathrm{SC2O2H} 2} \\
\delta_{\mathrm{SC} 303 \mathrm{H} 3} \\
\end{array}$ & 1076 & $\begin{array}{l}1044 \\
1028\end{array}$ & 1060 & $v_{\mathrm{C} 6-06}$ & & 202 & 75 & $\omega_{\mathrm{C} 505}$ \\
\hline 1321 & & & $\mathrm{v}_{\mathrm{C} 2-\mathrm{O} 2}$ & - & 942 & & $v_{\mathrm{C} 4 \mathrm{CS}}$ & & & & \\
\hline 1439 & $\begin{array}{l}1396 \\
1193 \\
\end{array}$ & 1298 & $\delta_{\mathrm{SC} 303 \mathrm{H} 3}$ & & & & & & 101 & 163 & $\tau_{\mathrm{CH} 2}$ \\
\hline 1388 & & & $\delta_{\text {SCSOSH OS }}$ & & & & & & & & $\omega_{\mathrm{C} 606}$ \\
\hline
\end{tabular}

${ }^{a} v=$ stretching, $\omega=$ wagging, out-of-plane ring bending, $\rho=$ in plane ring, $v_{s}=$ symmetric stretching bending, $\delta s=$ scissoring, angle bending, $\tau=$ twisting, $v_{\text {as }}=$ antisymmetric stretching, $\alpha=$ in plane deformation, $\gamma=$ out-of-plane deformation,

Table 3. Vibrational frequencies of compound 2, 3, 4 in the gas phase at B3LYP/6-311++G (d,p) level of theory.

\begin{tabular}{|c|c|c|c|c|c|c|c|c|c|c|c|}
\hline \multicolumn{3}{|c|}{ Frequency } & Assignment & \multicolumn{3}{|c|}{ Frequency } & Assignment & \multicolumn{3}{|c|}{ Frequency } & \multirow[t]{2}{*}{ Assignment } \\
\hline (2) & (3) & (4) & & (2) & (3) & (4) & & (2) & (3) & (4) & \\
\hline 3830 & 3764 & 3825 & $v_{\mathrm{O} 6-\mathrm{H}} \mathrm{O6}$ & 1460 & & & $\begin{array}{c}\delta_{\mathrm{SH} 3 \mathrm{O} 3 \mathrm{C} 3} \\
\mathrm{vo}_{5-\mathrm{H} 3}\end{array}$ & & & 720 & $v_{\mathrm{C} 3-\mathrm{C} 4}$ \\
\hline 3760 & 3737 & 3787 & $v_{\mathrm{O}-\mathrm{H}} \mathrm{O5}$ & 1390 & 1177 & & $\delta_{\mathrm{SC} 3 \mathrm{CHH} 4}$ & $\begin{array}{l}838 \\
280\end{array}$ & & & $v_{\text {О5-Н3 }}$ \\
\hline & 3777 & 3767 & $v_{\mathrm{O} 2-\mathrm{H} 2}$ & & 1264 & & $\delta_{\mathrm{SC} 303 \mathrm{H} 3}$ & \multirow[t]{2}{*}{807} & & & \multirow{2}{*}{$\begin{array}{l}\omega_{\mathrm{C} 101} \\
\omega_{\mathrm{C} 2 \mathrm{C} 3}\end{array}$} \\
\hline 3609 & 3831 & & $\mathrm{v}_{\mathrm{O} 3-\mathrm{H} 3}$ & & & 1374 & $\delta_{\mathrm{SC} 2 \mathrm{O} 2 \mathrm{H} 2}$ & & & & \\
\hline 3583 & 3690 & 3790 & $\left.\left(\mathrm{v}_{\mathrm{O} 1-\mathrm{H} 1}\right)_{5}\right)^{\mathrm{c}}$ & & 1125 & & $v_{\mathrm{C} 1-\mathrm{O} 1}$ & 340 & $\begin{array}{c}763 \\
46\end{array}$ & & $\begin{array}{l}\omega_{\mathrm{C} 101} \\
\omega_{\mathrm{C} 202}\end{array}$ \\
\hline
\end{tabular}




\begin{tabular}{|c|c|c|c|c|c|c|c|c|c|c|c|}
\hline \multirow{3}{*}{3212} & \multirow{3}{*}{3121} & \multirow{3}{*}{3075} & \multirow{3}{*}{$v_{\mathrm{C} 4-\mathrm{H} 4}$} & 1388 & $\begin{array}{l}1291 \\
1328 \\
1291\end{array}$ & 1119 & $\left(\begin{array}{c}\delta_{\mathrm{SC} 1 \mathrm{OrH} 1} \\
\left(\delta_{\mathrm{SC} 1 \mathrm{O} 1 \mathrm{H} 1}\right)_{5}\end{array}\right.$ & \multirow{3}{*}{737} & \multirow{3}{*}{464} & \multirow{3}{*}{$\begin{array}{l}697 \\
681 \\
638\end{array}$} & \multirow{3}{*}{$\begin{array}{l}\rho_{\mathrm{C} 10 \mathrm{r}} \\
\rho_{\mathrm{C} 202}\end{array}$} \\
\hline & & & & 1384 & & 1397 & $\begin{array}{c}\tau_{\mathrm{CH} 2} \\
\omega_{\mathrm{C} 5 \mathrm{H} 5}\end{array}$ & & & & \\
\hline & & & & 1367 & 1397 & $\begin{array}{l}1436 \\
1368 \\
1356 \\
\end{array}$ & $\begin{array}{c}\omega_{\mathrm{CH} 2}, \omega_{\mathrm{C} 5 \mathrm{H} 5}, \\
\omega_{\mathrm{O} 5 \mathrm{H} \mathrm{O} 5}, \delta_{\mathrm{SC} 6 \mathrm{O} 6 \mathrm{H}} \\
06\end{array}$ & & & & \\
\hline 3107 & 3118 & 3109 & $\mathrm{v}_{\text {as CH2 }}$ & 1332 & & & $\begin{array}{l}\omega_{\mathrm{C} 5 \mathrm{H} 5} \\
\rho_{\mathrm{C} 4 \mathrm{H} 4}\end{array}$ & $\begin{array}{c}275 \\
107 \\
91 \\
30\end{array}$ & $\begin{array}{c}442 \\
599 \\
175 \\
273 \\
84 \\
173 \\
\end{array}$ & $\begin{array}{l}822 \\
561\end{array}$ & $\mathrm{dc}$ \\
\hline 3041 & 3045 & 3019 & $\mathrm{v}_{\mathrm{s} \mathrm{CH} 2}$ & 1282 & & & $\begin{array}{c}\delta_{\mathrm{SC} 5 \mathrm{O} 5 \mathrm{H} 05} \\
\omega_{\mathrm{C} 5 \mathrm{H} 5} \\
\rho_{\mathrm{O} 5 \mathrm{H} 05} \\
\end{array}$ & & $\begin{array}{l}558 \\
773\end{array}$ & & $\delta_{\mathrm{SOrC1O1}}$ \\
\hline \multirow{2}{*}{3041} & \multirow{2}{*}{3045} & \multirow{2}{*}{3019} & \multirow{2}{*}{$v_{\mathrm{sCH} 2}$} & 1244 & 1249 & & $\delta_{\text {SCSOSH OS }}$ & \multirow{2}{*}{$\begin{array}{l}700 \\
253\end{array}$} & \multirow{2}{*}{$\begin{array}{l}706,333 \\
309,237 \\
371,343\end{array}$} & & \multirow{2}{*}{$\begin{array}{l}\omega_{\mathrm{O} 3 \mathrm{H} 3} \\
\omega_{\mathrm{C3C4}}\end{array}$} \\
\hline & & & & & 1217 & 1182 & $\delta_{\mathrm{SC} 2 \mathrm{O} 2 \mathrm{H} 2}$ & & & & \\
\hline 1827 & 1822 & & $\mathrm{v}_{\mathrm{Cl}=\mathrm{O} 1}$ & & & 1263 & $\begin{array}{c}\delta_{\mathrm{SC} 5 \mathrm{CH} 4} \\
\omega_{\mathrm{C} 5 \mathrm{H} 5} \\
\rho_{\mathrm{C} 4 \mathrm{H} 4} \\
\end{array}$ & 658 & & & $\begin{array}{l}\rho_{\mathrm{C} 3 \mathrm{O} 3} \\
\rho_{\mathrm{C} 4 \mathrm{H} 4}\end{array}$ \\
\hline \multirow[t]{3}{*}{1722} & & & $v_{\mathrm{C} 2=\mathrm{O} 2}$ & $\begin{array}{l}1188 \\
1162\end{array}$ & 1187 & $\begin{array}{l}1252 \\
1382 \\
1299\end{array}$ & $\begin{array}{l}\delta_{\mathrm{SC} 3 \mathrm{C} 4 \mathrm{H} 4} \\
\omega_{\mathrm{CH} 4} \\
\rho_{\mathrm{ClO1}} \\
\rho_{\mathrm{O} 1 \mathrm{H} 1} \\
\end{array}$ & 615 & & $\begin{array}{c}55 \\
524\end{array}$ & $\begin{array}{l}\omega_{\mathrm{C} 303} \\
\rho_{\mathrm{C} 4 \mathrm{C5}}\end{array}$ \\
\hline & & 1700 & $\mathrm{v}_{\mathrm{C} 3=\mathrm{O}}$ & & & 1053 & $\delta_{\mathrm{SC} 3 \mathrm{C} 4 \mathrm{H} 4}$ & \multirow{2}{*}{$\begin{array}{l}383 \\
424\end{array}$} & \multirow[t]{2}{*}{486} & & \multirow{2}{*}{$\begin{array}{l}\rho_{\mathrm{C6C5}} \\
\omega_{\mathrm{O} \mathrm{H} 5}\end{array}$} \\
\hline & 1701 & & $\mathrm{v}_{\mathrm{C4} 4=\mathrm{C5} \text { (S-Cis) }}$ & & & 234 & $\delta_{\mathrm{SC} 3 \mathrm{C} 2 \mathrm{O} 2}$ & & & & \\
\hline \multirow[t]{3}{*}{1673} & & & $v_{\mathrm{C} 3=\mathrm{C} 4}$ & $\begin{array}{l}1036 \\
1123\end{array}$ & 1016 & $\begin{array}{l}1140 \\
875\end{array}$ & $v_{\text {C5-O5 }}$ & 340 & $\begin{array}{l}486 \\
522 \\
495\end{array}$ & $\begin{array}{c}148 \\
94 \\
73 \\
60\end{array}$ & $\mathrm{dc}^{\mathrm{b}}$ \\
\hline & 1686 & 1463 & $\mathrm{v}_{\mathrm{C} 2=\mathrm{C} 3}$ & 1036 & 1016 & & $v_{\mathrm{C} 3-03}$ & & $\begin{array}{l}522 \\
495\end{array}$ & $\begin{array}{l}309 \\
295\end{array}$ & $\mathrm{dc}$ \\
\hline & & 1805 & $v_{\mathrm{Cl}=\mathrm{C} 2}$ & $\begin{array}{l}1010 \\
1051 \\
\end{array}$ & $\begin{array}{c}983 \\
1046 \\
\end{array}$ & $\begin{array}{c}1068 \\
996 \\
\end{array}$ & $v_{\mathrm{C} 6-\mathrm{O} 6}$ & & & 382 & $\begin{array}{l}\omega_{\mathrm{ClOr}} \\
\omega_{\mathrm{O} 1 \mathrm{H} 1}\end{array}$ \\
\hline 1491 & 1499 & 1495 & $\delta_{\mathrm{SCH} 2}$ & & & $\begin{array}{r}927 \\
1031\end{array}$ & $\begin{array}{l}v_{\mathrm{CA}-\mathrm{Or}} \\
\rho_{\mathrm{C} 4 \mathrm{CS}} \\
\end{array}$ & & & 353 & $\rho_{\mathrm{O} 1 \mathrm{H} 1}$ \\
\hline \multirow[t]{2}{*}{1409} & 1424 & & $\delta_{\mathrm{SC} 5 \mathrm{C} 4 \mathrm{H} 4}$ & & 854 & & $\begin{array}{l}\omega_{\mathrm{C} 4 \mathrm{H} 4} \\
\omega_{\mathrm{C} 5 \mathrm{OS}}\end{array}$ & & & $\begin{array}{l}273 \\
341 \\
314 \\
\end{array}$ & $\begin{array}{l}\omega_{\mathrm{O} 1 \mathrm{H} 1} \\
\omega_{\mathrm{ClC} 2} \\
\omega_{\mathrm{O} 2 \mathrm{H} 2} \\
\end{array}$ \\
\hline & 1408 & & $\delta_{\mathrm{SC} 2 \mathrm{O} 2 \mathrm{H} 2}$ & \multirow{3}{*}{$\begin{array}{l}877 \\
859\end{array}$} & \multirow{3}{*}{$\begin{array}{l}668 \\
872 \\
854 \\
130\end{array}$} & & \multirow{3}{*}{$\mathrm{dc}$} & & & $\begin{array}{l}238 \\
450\end{array}$ & $\begin{array}{c}\omega_{\mathrm{C} 4 \mathrm{CS} 5} \\
\omega_{\mathrm{O} 5 \mathrm{H} \mathrm{O5}} \\
\end{array}$ \\
\hline \multirow{2}{*}{1409} & \multirow{2}{*}{1365} & & \multirow{2}{*}{$\delta_{\mathrm{SO} 6 \mathrm{C} 6 \mathrm{H} 6(1)}{ }^{\mathrm{c}}$} & & & & & $\begin{array}{l}291 \\
296 \\
\end{array}$ & $\begin{array}{l}495 \\
486 \\
\end{array}$ & 511 & $\begin{array}{c}\omega_{\mathrm{O} 6 \mathrm{H} \mathrm{O6}} \\
\tau_{\mathrm{CH} 2}\end{array}$ \\
\hline & & & & & & & & 972 & 784 & & $\begin{array}{l}\omega_{\mathrm{C} 3 \mathrm{C} 4} \\
\omega_{\mathrm{C} 1 \mathrm{C} 2}\end{array}$ \\
\hline
\end{tabular}

${ }^{a} v=$ stretching, $\omega=$ wagging, out-of-plane ring bending, $\rho=$ in plane ring, $v_{s}=$ symmetric stretching bending, $\delta s=$ scissoring, angle bending, $\tau=$ twisting, $v_{\text {as }}=$ antisymmetric stretching, $\alpha=$ in plane deformation, $\gamma=$ out-of-plane deformation.

${ }^{\mathrm{b}} \mathrm{dc}=$ deformation of compound.

\section{2. 2 Tautomers of 2,3 , and 4 (gas phase)}

The $\mathrm{O}_{6}-\mathrm{H}_{06}$ stretching mode $\mathbf{2 , 3}$ and $\mathbf{4}$ was calculated at 3830, 3764, and $3825 \mathrm{~cm}^{-1}$, respectively. The second stretching mode for the $\mathrm{O}_{5}-\mathrm{H}_{05}$ bond was calculated at 3760,3737 , and $3787 \mathrm{~cm}^{-1}$ for tautomers $\mathbf{2 , 3}$ and $\mathbf{4}$, respectively. The third stretching mode $\mathrm{O}_{3}-\mathrm{H}_{3}$ for $\mathbf{2}$ and $\mathbf{3}$ tautomers appeared at 3609 and $3831 \mathrm{~cm}^{-1}$. The fourth stretching mode for the $\mathrm{O}_{2}-\mathrm{H}_{2}$ bond was calculated at 3777 and $3767 \mathrm{~cm}^{-1}$ for 3 and 4, respectively. The fifth stretching mode for the $\mathrm{O}_{\mathrm{r}}-\mathrm{H}_{\mathrm{O} 1}$ bond calculated at 3583 and $3690 \mathrm{~cm}^{-1} \mathbf{2}$ and $\mathbf{3}$ tautomers. The stretching mode for the $\mathrm{O}_{1}-\mathrm{H}_{\mathrm{O} 1}$ bond was calculated at $3790 \mathrm{~cm}^{-1}$ for 4 . There were two stretching modes for $\mathrm{O}_{5} \ldots \mathrm{H}_{3}$ hydrogen at 838 and $280 \mathrm{~cm}^{-1}$ for 3 .

$C=O$ modes. The $\mathrm{C}_{1}=\mathrm{O}_{1}$ stretching mode of $\mathbf{2}$ and $\mathbf{3}$ were observed at 1827 and $1822 \mathrm{~cm}^{-1}$, respectively. The second stretching mode for the $\mathrm{C}_{2}=\mathrm{O}_{2}$ bond appeared at $1722 \mathrm{~cm}^{-1}$ for isomer 2 . The third stretching mode of $\mathrm{C}_{3}=\mathrm{O}_{3}$ bond was calculated at $1700 \mathrm{~cm}^{-1}$ for 4 .

$C=C$ modes. The $\mathrm{C}_{2}=\mathrm{C}_{3}$ stretching mode of $\mathbf{3}$ and $\mathbf{4}$ appeared at 1686 and $1463 \mathrm{~cm}^{-1}$, respectively. The second stretching mode for the $\mathrm{C}_{1}=\mathrm{C}_{2}$ bond was calculated at $1805 \mathrm{~cm}^{-1}$ for isomer 4 . The third stretching mode for the $\mathrm{C}_{3}=\mathrm{C}_{4}$ 
bond was found at $1673 \mathrm{~cm}^{-1}$ for tautomer 2 . The $\mathrm{C}_{4}=\mathrm{C}_{5}$ stretching mode for 3 was observed at $1701 \mathrm{~cm}^{-1}$, respectively.

$\mathrm{C}-\mathrm{H}$ modes. The stretching mode $\mathrm{C}_{4}-\mathrm{H}_{4}$ for tautomers $\mathbf{2 ,} 3$ and $\mathbf{4}$ were calculated at 3212, 3121 and $3075 \mathrm{~cm}^{-1}$. The stretching mode $\mathrm{C}_{5}-\mathrm{H}_{5}$ of 2 and 4 was obtained at 2953 and $2960 \mathrm{~cm}^{-1}$, respectively. The anti-symmetric stretching modes of $\mathrm{CH}_{2}$ were found at 3107, 3118 and $3109 \mathrm{~cm}^{-1}$ for $\mathbf{2 , 3}$ and 4. The symmetric stretching mode of $\mathrm{CH}_{2}$ was found at 3041,3045 , and 3019 $\mathrm{cm}^{-1}$. The scissoring mode for the $\mathrm{CH}_{2}$ was found at 1491,1499 , and $1495 \mathrm{~cm}^{-1}$ for $\mathbf{2 , 3}$ and $\mathbf{4}$ isomers, respectively.

$\mathrm{C}-\mathrm{O}$ modes. The $\mathrm{C}_{4}-\mathrm{O}_{4}$ stretching modes for $\mathbf{2}, \mathbf{3}$ and $\mathbf{4}$ were observed at 1051, 983 and $996 \mathrm{~cm}^{-1}$, respectively. The $\mathrm{C}_{3}-\mathrm{O}_{3}$ stretching modes for $\mathbf{2}$ and $\mathbf{3}$ were observed at 1036 and $1016 \mathrm{~cm}^{-1}$. The $\mathrm{C}_{5}-\mathrm{O}_{5}$ stretching mode of $\mathbf{2 , 3}$ and $\mathbf{4}$ tautomers were observed at 1036,1016 and $1140 \mathrm{~cm}^{-1}$, respectively. The $\mathrm{C}_{1}-\mathrm{O}_{1}$ stretching mode of 3 was observed at $1125 \mathrm{~cm}^{-1}$. The $\mathrm{C}_{4}-\mathrm{O}_{\mathrm{r}}$ stretching mode of 4 was observed at $972 \mathrm{~cm}^{-1}$.

$C$-C modes. The $\mathrm{C}_{3}-\mathrm{C}_{4}$ stretching mode of 4 was observed at $720 \mathrm{~cm}^{-1}$.

4. 3 NMR spectrum

4.3.1 NMR spectrum L-ascorbic acid

${ }^{1} H$-NMR: The experimental proton chemical shifts in $\mathrm{D}_{2} \mathrm{O}$ were found at $\mathrm{H}_{4}=4.8, \mathrm{H}_{5}=3.9, \mathrm{H}_{6=} 3.6, \mathrm{H}_{6=} 3.6 \mathrm{ppm}$ (Table 4). The experimental value in the DMSO and theoretical calculations in both gas and water phase predict that the proton $\mathrm{H}_{3}$ the most deshielded chemical shift which complements the finding of reference 32. That $\mathrm{L}$-Ascorbic acid is a weak dibasic acid ( $\mathrm{pKa}_{1}=4.25$ and $\mathrm{pKa}_{2}=11.79$ ), the monoanion forms at $\mathrm{pH} 4-5$ by deprotonation from $\mathrm{O}_{3}-\mathrm{H}_{3}$ bond. The experimental chemical shifts of $\mathrm{H}_{\mathrm{O} 6}$ and $\mathrm{H}_{\mathrm{O} 5}$ in DMSO appeared at $4.9 \mathrm{ppm}$.

Table 4. ${ }^{1} \mathrm{H}-\mathrm{NMR}$ and ${ }^{13} \mathrm{C}-\mathrm{NMR}$ spectrums of L-ascorbic acid (1): Experimental and calculated values at DFT levels of theory using B3LYP/6-311+G(2d,p) basis set in the gas and water phase.

\begin{tabular}{|c|c|c|c|c|c|c|c|c|c|c|}
\hline \multicolumn{11}{|c|}{$\begin{array}{l}{ }^{1} \mathrm{H}-\mathrm{NMR}(\mathrm{TMS} \text { B3LYP/6-311+G(2d,p) GIAO) } \\
\text { (1) }\end{array}$} \\
\hline$\Delta \delta$ & $\begin{array}{l}\text { Cal. } \\
\text { Water }\end{array}$ & $\Delta \delta$ & $\begin{array}{c}\text { Cal. } \\
\text { DMSO }\end{array}$ & $\Delta \delta$ & Cal. $\mathrm{Gas}^{\mathrm{c}}$ & $\Delta \delta$ & Exp. $\left(\mathrm{D}_{2} \mathrm{O}\right)$ & $\Delta \delta^{\mathrm{b}}$ & Exp.(DMSO) ${ }^{a}$ & Assignment \\
\hline-1.5 & 1.8 & -1.2 & 2.1 & -3.3 & $0.0-$ & & - & 1.5 & 4.9 & $\mathrm{H}_{\mathrm{O} 6}$ \\
\hline 0.5 & 3.8 & 0.9 & 4.2 & -0.3 & 3.0 & & - & 1.5 & 4.9 & $\mathrm{H}_{\mathrm{O} 5}$ \\
\hline 4.1 & 7.4 & 4 & 7.3 & 3.3 & 6.6 & & - & 7.6 & 11.0 & $\mathrm{H}_{3}$ \\
\hline 2.1 & 5.4 & 2.1 & 5.4 & 1.6 & 4.9 & 1.2 & 4.8 & 0.8 & 4.2 & $\mathrm{H}_{4}$ \\
\hline 1.4 & 4.7 & 1.3 & 4.6 & 1 & 4.3 & 0.3 & 3.9 & 0.3 & 3.7 & $\mathrm{H}_{5}$ \\
\hline 0.7 & 4.0 & 0.6 & 3.9 & 0.7 & 4.0 & 0 & 3.6 & 0.1 & 3.5 & $\mathrm{H}_{6}$ \\
\hline 0 & 3.3 & 0 & 3.3 & 0 & 3.3 & 0 & 3.6 & 0 & 3.4 & $\mathrm{H}_{6}$ \\
\hline 1.6 & 4.9 & 2.4 & 5.7 & -0.1 & 3.2 & & - & 5 & 8.4 & $\mathrm{H}_{2}$ \\
\hline \multicolumn{11}{|c|}{$\begin{array}{c}{ }^{13} \mathrm{C}-\mathrm{NMR} \text { [TMS B3LYP/6-311+G(2d,p) GIAO ] } \\
\text { (1) }\end{array}$} \\
\hline \multicolumn{2}{|l|}{$\Delta \delta$} & \multicolumn{2}{|l|}{ Cal. Water } & $\Delta \delta$ & \multicolumn{2}{|l|}{ Cal. gas } & \multicolumn{2}{|l|}{$\Delta \delta$} & Exp.(DMSO) & Assignment \\
\hline \multicolumn{2}{|l|}{110.4} & \multicolumn{2}{|l|}{174.8} & 103.0 & \multicolumn{2}{|l|}{169.1} & \multicolumn{2}{|l|}{108.7} & 170.6 & $\mathrm{C}_{1}$ \\
\hline \multicolumn{2}{|l|}{61.7} & \multicolumn{2}{|l|}{126.1} & 61.2 & \multicolumn{2}{|l|}{127.3} & \multicolumn{2}{|l|}{56} & 117.9 & $\mathrm{C}_{2}$ \\
\hline \multicolumn{2}{|l|}{98.0} & \multicolumn{2}{|l|}{162.4} & 90.1 & \multicolumn{2}{|l|}{156.2} & \multicolumn{2}{|l|}{91} & 152.9 & $\mathrm{C}_{3}$ \\
\hline \multicolumn{2}{|l|}{10.9} & \multicolumn{2}{|l|}{75.3} & 8.1 & \multicolumn{2}{|l|}{74.2} & \multicolumn{2}{|l|}{12.9} & 74.8 & $\mathrm{C}_{4}$ \\
\hline \multicolumn{2}{|l|}{13.6} & \multicolumn{2}{|l|}{78.0} & 13.6 & \multicolumn{2}{|l|}{79.7} & \multicolumn{2}{|l|}{6.4} & 68.3 & $\mathrm{C}_{5}$ \\
\hline \multicolumn{2}{|l|}{0} & \multicolumn{2}{|l|}{65.4} & 0 & \multicolumn{2}{|l|}{66.1} & \multicolumn{2}{|l|}{0} & 61.9 & $\mathrm{C}_{6}$ \\
\hline
\end{tabular}

experimental NMR contains water.

${ }^{\mathrm{a}}$ Exp. $=$ Experimental.

${ }^{\mathrm{b}} \Delta=$ The chemical shift relative to the most shielded $\mathrm{H}_{6}$ of ${ }^{1} \mathrm{H}-\mathrm{NMR}$ and $\mathrm{C}_{6}$ of ${ }^{13} \mathrm{C}-\mathrm{NMR}$ spectra DMSO used in

${ }^{\mathrm{c}}$ Cal. $=$ Calculated.

${ }^{13} \mathrm{C}$-NMR: Experimental carbon chemical shifts of 1 were obtained at $\mathrm{C}_{1}=170.6, \mathrm{C}_{3}=152.9, \mathrm{C}_{2}=117.9, \mathrm{C}_{4}=74.8, \mathrm{C}_{5}=68.3, \mathrm{C}_{6}=61.9$ in DMSO (Table 4). The calculated chemical shifts were found at $C_{1}=169.1, C_{3}=156.2, C_{2}=127.3$, $\mathrm{C}_{5}=79.7, \mathrm{C}_{4}=74.8, \mathrm{C}_{6}=66.1$ in the gas phase. The calculated chemical shifts of carbons were observed at $\mathrm{C}_{1}=174.8, \mathrm{C}_{3}=162.4, \mathrm{C}_{2}=126.1, \mathrm{C}_{5}=78.0, \mathrm{C}_{4}=75.3$, $\mathrm{C}_{6}=65.4$ in water phase.
4.3.2 Calculated NMR spectrum of tautomers 2-4

${ }^{1} H$-NMR. The calculated chemical shifts of tautomers of L-ascorbic acid in the gas phase are presented in Table 5. The most acidic hydrogen of tautomers of $\mathrm{L}$-ascorbic acid is $\mathrm{H}_{4}$ that appeared at 9.7, 11.1 and $3.9 \mathrm{ppm}$ for isomers 2, 3 and $\mathbf{4}$ respectively. 
Table 5. Calculated ${ }^{1} \mathrm{H}-\mathrm{NMR}$ and ${ }^{13} \mathrm{C}-\mathrm{NMR}$ spectrums of compound 2,3 and 4 at DFT levels of theory using B3LYP/6-311+G(2d,p) basis set in gas phase.

\begin{tabular}{|c|c|c|c|c|c|c|}
\hline \multicolumn{7}{|c|}{${ }^{1} \mathrm{H}-\mathrm{NMR}$ [ TMS B3LYP/6-311+G(2d,p) GIAO] } \\
\hline$\Delta \delta$ & (4) & $\Delta \delta$ & (3) & $\Delta \delta^{\mathrm{a}}$ & (2) & Assignment \\
\hline 0.0 & -0.8 & 0.0 & -0.5 & 0.0 & -0.7 & $\mathrm{H}_{\mathrm{O} 6}$ \\
\hline 2.4 & 1.6 & 4.6 & 4.1 & 2.7 & 2.0 & $\mathrm{H}_{\mathrm{O} 5}$ \\
\hline- & - & 7.4 & 6.9 & 6.2 & 5.5 & $\mathrm{H}_{3}$ \\
\hline 4.7 & 3.9 & 11.6 & 11.1 & 10.4 & 9.7 & $\mathrm{H}_{4}$ \\
\hline 4.5 & 3.7 & - & - & 4.8 & 4.1 & $\mathrm{H}_{5}$ \\
\hline 4.0 & 3.2 & 4.4 & 3.9 & 3.8 & 3.1 & $\mathrm{H}_{6}$ \\
\hline 4.1 & 3.3 & 4.5 & 4.0 & 4.2 & 3.5 & $\mathrm{H}_{6}$ \\
\hline 3.9 & 3.1 & 4.0 & 3.5 & - & - & $\mathrm{H}_{2}$ \\
\hline 4.0 & 3.2 & 5.8 & 5.3 & 6.8 & 6.1 & $\mathrm{H}_{\mathrm{Or}}$ \\
\hline \multicolumn{7}{|c|}{${ }^{13} \mathrm{C}-\mathrm{NMR}$ [TMS B3LYP/6-311+G(2d,p) GIAO] } \\
\hline$\Delta \delta$ & (4) & $\Delta \delta$ & (3) & $\Delta \delta$ & (2) & Assignment \\
\hline 129.9 & 197.9 & 118.6 & 185.3 & 107.0 & 176.4 & $\mathrm{C} 1$ \\
\hline 79.4 & 147.4 & 78.0 & 144.7 & 118.0 & 187.4 & $\mathrm{C} 2$ \\
\hline 150.2 & 218.2 & 105.2 & 171.9 & 108.0 & 177.4 & $\mathrm{C} 3$ \\
\hline 21.8 & 89.8 & 53.7 & 120.4 & 68.5 & 137.9 & $\mathrm{C} 4$ \\
\hline 9.7 & 77.7 & 103.0 & 169.7 & 10.2 & 79.6 & $\mathrm{C} 5$ \\
\hline 0 & 68.0 & 0 & 66.7 & 0 & 69.4 & C6 \\
\hline
\end{tabular}

a $\Delta \delta$ The chemical shift relative to the most shielded proton and carbon.

${ }^{13} \mathrm{C}-\mathrm{NMR}$ : The calculated carbon chemical shifts of $\mathbf{2}$ was observed at $\mathrm{C}_{2}=187.4, \mathrm{C}_{3}=177.4, \mathrm{C}_{1}=176.4, \mathrm{C}_{4}=137.9, \mathrm{C}_{5}=79.6, \mathrm{C}_{6}=69.4$. The calculated carbon chemical shifts of $\mathbf{3}$ for $\mathrm{C}_{1}$ (corresponding to carboxylic acid group) was observed at $185.3 \mathrm{ppm}$. The chemical shifts of the $\mathrm{C}_{2}$ and $\mathrm{C}_{3}$ atoms of the enol form were observed at 144.7 and $171.9 \mathrm{ppm}$, respectively. The chemical shift of $\mathrm{C}_{4}, \mathrm{C}_{5}$ and $\mathrm{C}_{6}$ atoms was calculated at $120.4,169.7$ and $66.7 \mathrm{ppm}$, respectively. The calculated carbon chemical shifts of $\mathbf{4}$ appeared at 197.9, 147.4, 268.2, 89.8, 77.7 and 68.0 ppm for $\mathrm{C}_{1}, \mathrm{C}_{2}, \mathrm{C}_{3}, \mathrm{C}_{4}, \mathrm{C}_{5}$ and $\mathrm{C}_{6}$, respectively.

\section{CONCLUSION}

The single-excitation configuration interaction TD-DFT calculations of molecular orbital geometry in the gas and water phase predicted that the visible absorption maxima of the L-ascorbic acid correspond to the electron transition from HOMO to LUMO which attributed to maximum amount of the $f$ values with the highest $\%$ absorption. The $\lambda$ for L-ascorbic acid was calculated $238 \mathrm{~nm}$ max in the gas phase. This value was increased to $248 \mathrm{~nm}$ in the water phase (the solvent effects).

The order of $v(\mathrm{O}-\mathrm{H})$ modes for $\mathrm{L}$-ascorbic acid were obtained experimentally $\mathrm{v}\left(\mathrm{O}_{3}-\mathrm{H}_{3}\right)>\left(\mathrm{O}_{6}-\mathrm{H}_{\mathrm{O}}\right)>\left(\mathrm{O}_{2}-\mathrm{H}_{2}\right)>\left(\mathrm{O}_{5}-\mathrm{H}_{05}\right.$. The calculated values are $\left.v) \mathrm{O}_{6}-\mathrm{H}_{\mathrm{O}}\right)>\left(\mathrm{O}_{2}-\mathrm{H}_{2}\right)>\left(\mathrm{O}_{5}-\mathrm{H}_{05}\right)>\left(\mathrm{O}_{3}-\mathrm{H}_{3}(\right.$ in the gas phase and $v\left(\mathrm{O}_{3}-\mathrm{H}_{3}\right)>\left(\mathrm{O}_{5}-\mathrm{H}_{05}\right)>\left(\mathrm{O}_{6}-\mathrm{H}_{\mathrm{O}}\right)>\left(\mathrm{O}_{2}-\mathrm{H}_{2}\right.$ (in water phase. The two stretching modes for the $\mathrm{O}_{5} \ldots \mathrm{H}_{3}$ hydrogen were measured at 838 and $280 \mathrm{~cm}^{-1}$ for the compound of 3 .

The experimental (in DMSO) and theoretical calculation chemical shifts of $\mathrm{L}$-ascorbic acid predicted proton $\mathrm{H}_{3}$ the most deshielded chemical shift. The most acidic hydrogen of tautomers of L-ascorbic acid is $\mathrm{H}_{4}$ that appeared at 9.7, $\mathbf{1 1 . 1}$ and $\mathbf{3 . 9}$ for the $\mathbf{2}, \mathbf{3}$ and $\mathbf{4}$, tautomers, respectively.

\section{REFERENCES}

1. K.A. Naidu, Nutr. J., 2, 1, (2003).

2. L.D. Muller, J. Pharm. Biomed. Anal. 25, 985, (2001).

3. R. Olson, "Water soluble vitamins. In: Principles of Pharmacology Edited by: Munson, P.; Mueller, R.; Chapman, B. G.; Hall, B. G.; New York, 1999: Ch 59 .

4. L. Hallberg, Annu Rev. Nutr. 1, 123, (1981).

5. C.I. Rivas, J.C. Vera, V.H. Guaiquil, F.V. Velasquez, O.A. Borquezojeda, J.G. Carcamo, I.I. Concha, D.W. Golde, J. Biol. Chem. 272, 5814, (1997).
6. B. Halliwell, J. Gutteridge, Free radicals in Biology and Medicine. Oxford University Press, 3rd ed. Oxford, 1999.

7. H. Kobayashi, H. Akamine, Y. Okawa, T. Ohno, S. Mizusawa, Electrochimica Acta. 36, 1649, (1991).

8. Y. Dimitrova, Spectrochimica Acta A. 63, 427, (2006).

9. R.A. Yadav, P. Rani, M. Kumar, R. Singh, P. Singh, N. P. Singh, Spectrochimica Acta A 84, 6, (2011).

10. P. J. Nyman, W. G. Wamer, T. H. Begley, G. W. Diachenko, G. A. J. Food Science 75, C263 (2010).

11. D. Giuntini, G. Graziani, B. Lercari, V. Fogliano, G. F. Soldatini, A. Ranieri, J. Agric. Food Chem. 53, 3174 (2005).

12. R. Kandar, P. Drabkova, R. Hampl, A. Ranieri, J. Chromatogr. B 879, 2834, (2011).

13. A.R. Medina, M.L.F. Cordora, A.M. Diaz, J. Pharm. Biomed. Anal. 20, 247, (1999).

14. M. Surmeian, Ind. Pharm. 24, 691 (1998).

15. L. Shen, H.F. Ji, H.Y. J. Mol. Struct. (Theochem) 821, 171, (2007).

16. H.Y Zhang, Curr. Comput. Aided Drug Des. 1, 257, (2005).

17. L. Shen, H.F. Ji, H.Y. Zhang, Bio org. Med. Chem. Lett. 16, 1414, (2006).

18. J. R. Juhasz, L.F. Pisterzi, D.M. Gasparro, D. R. P. Almeida, J. Mol. Struct. (Theochem) 666-667, 401, (2003).

19. O. R. Miranda, N. R. Dollahon, T. S. Ahmadi, Cryst. Growth Des. 6, 2747, (2006) 2753.

20. I. Georgieva, N. Trendafilova, Chem. Phys. 321, 311, (2006).

21. A. Ruchmann, J. Lauterwein, N. T. Backer, M. Klessinger, Magn. Reson. Chem., 34, 116, (1996).

22. D.M. Bailey, W. O. George, M. Gutowski, J. Mol. Struct. (Theochem) 910, 61, (2009).

23. V. V. Konya, P.G. Meszaros, B. Viskolcz, I. G Csizmadia J. Mol. Struct. (Theochem) 666-667, 397 (2003).

24. G. A. Dilabio, J. S. Wright, Free Radical Bio. Med. 29, 480, (2000).

25. M. J. Frisch, et al. Gaussian 03, Revision C.02, Gaussian, Inc., Wallingford CT, 2004

26. E. Cances, B. Mennucci, J. Tomasi, J. Chem. Phys. 107, 3032, (1997).

27. M. Cossi; V. Barone, B. Mennucci, J. Tomasi, Chem. Phys. Lett. 286, 253, (1998).

28. B. Mennucci, J. Tomasi, J. Chem. Phys. 106, 5151 (1997).

29. M. Cossi, G. Scalmani, N. Rega, V. Barone, J. Chem. Phys. 117, 43, (2002).

30. E. DeRitter, L. Magid, M. Osadca, S. H. J. Pharm. Sci. 59, 229, (1970). 